\title{
AN EFFORT TO IMPROVE THE STUDENTS' COMMUNICATION THROUGH ASSIGNMENTS AND PEER EMPOWERMENT IN MATHEMATICS
}

\author{
Lukmanul Akhsani, M.Pd \\ Universitas Muhammadiyah Purwokerto \\ Purwokerto, Indonesia
}

\author{
Anggun Badu Kusuma, M.Pd \\ Universitas Muhammadiyah Purwokerto \\ Purwokerto, Indonesia
}

\begin{abstract}
This study aimed to improve students' communication through assignments and the peer empowerment in mathematics. This is a Classroom Action Research held in two cycles. Each cycle consisted of two meetings. The result showed that the score of students' communication in the first meeting was 1.875 in very low category and it scored 2 in the second meeting in fair category. Therefore, it needed the second cycle. In the first meeting of the second cycle, the ability of the students' communication improved to 3.125 in good category, then, it increased more in the second meeting with 3.37 (good category). It could be concluded that the students' communication through peer empowerment on mathematics learning media improved.
\end{abstract}

Keywords: Communication, Assignment, Peer, Media.

\section{Introduction}

Learning process is an interaction between teachers and students in a learning process to get the learning achievement. The assignment method is one way to create an interesting and attractive teaching process to support the best teaching method. It needs guidance process in assignment method.

The guidance is not a single activity, it involves various and continuous actions. The guidance is unintentionally not given, it is a systematic, directed, and designed activities to achieve learning goals. (Kartadinata :1996).

In case of Learning Media subject, it needs good comprehension about learning media. It affects students when arranging the learning media concept. It can be seen during the discussion in class, they argue to each other about media, the characteristics of media, and the benefits of media. The ability of students' communication affects significantly to the students' discussion in learning process.

The ability of the students' mathematics communication is the ability to interpret the idea of mathematics orally, written or demonstrate it. The students are only able to answer the questions given in short answer. It needs discussion with other students in the class, in this case peers, in order to create better communication among them.

The other benefits of communicating with peers is that the students are able to express their own arguments, train students to create good communication, and improve the students' activities and cooperation with each other. Discussion with peers would create improve a better two-way communication because they would not hesitate to ask the questions about learning media they have not understood yet. On the contrary, their friends would never hesitate to guide their friends. The guidance related to the assignment would be fair by involving peers. The limitation of lecturers in guiding all students in composing the media could be solved by the empowerment of peers.

Based on above description, this research aimed to improve students' communication through assignments by peer empowerment in mathematics learning media.

Communications (conceptually) is revealing and sharing out some knowledge, thoughts, and values in order to boost participation so that the information becomes the mutual possessions.

Communication is classified into some methods. It can be classified into :

1. Verbal communication (communication using words). Verbal communication is divided into oral and written verbal communication

2. Nonverbal communication (communication without words or messages stated in media except linguistic media

According to Sumarmo (2004), there are some indicators showing the ability of mathematical communication, namely:

1. connecting real objects, images, and diagrams into mathematics idea;

2. explaining ideas, situations and mathematical relationships, orally or written with real objects, drawings, graphs and algebra;

3. declaring daily events in language or by mathematics symbol;

4. listening, discussing, and writing about mathematics;

5. reading by understanding written mathematical presentation.

The definition and Objectives of Assignment becomes one way of teaching designed for students to be excited and attracted to find their own answers 
given. The purpose of using the assignment method is to stimulate the students to actively study individually or in groups (Sumantri, 2001).

The strengths of using this assignment method are:

1. Making students for active learning.

2. Stimulating students to learn more, either with the teacher inside the class or without the teacher when away

3. Developing students' independence.

4. Being more convinced, deepened, extended, and enriched than that of what the lecturer has already taught.

5. Fostering the habits of students to seek and process their own information and communication.

6. Making students passionate about learning because it presents various learning.

7. Developing students' creativity.

According to Muzaqi (2007), the role that can be played by the companion is:

1. The Role of Motivator. The work done by the companion is to awaken and encourage the group to recognize potential and problems, as well as develop its potential to solve the problem.

2. The Role of the Facilitator. Companions are responsible to create a climate of harmonious group and to facilitate the process of mutual learning in groups.

3. The Role of Catalysts. The facilitator in this case can perform activities as a liaison between the advisory group with outside agencies group or other technical institutions, both technical service institutions capital and service skill services in the framework of network development.

\section{Research method}

This is a Classroom Action Research whis was conducted in 2 cycles, each cycle consisted of 2 meetings. This research was carried out in class A with 40 students. The research procedures were conducted in some cycles, namely:

1. Planning

It includes planning, exercise material, task discussion, tasks, questions, tests.

2. Action

a. Students were motivated and motivated by Lecturers.

b. The lecturer presented problems to the students.

c. The students designed problem solving frameworks and the process how to succeed.

d. Students were evaluated

e. Students could reflect to see what they have done f. The quality of final result of the product was under quality control.

3. Observation

Observations are made to find out the effectiveness of learning on the subject related to communication skills.

4. Reflection

Discussion of each cycle was done to determine the conclusion or result of research.

\section{Result and Discussion}

The study was conducted in two cycles, with one meeting in each meeting The results as follows.

CYCLE 1

1. Planning

The activities done in this stage was:

a. Composing the RPS for two meetings. Lesson Plan activities are tailored for peer empowerment.

b. Arranging the observation sheets of students' communication .

2. Action

c. Preparing equipment for documentation.

The action was done twice. The lecturer was more focused on directing the discussion activities. Students presented their own independent duties on mathematics learning media. The activities in general are as follows:

a. The lecturer checked for the students' readiness.

b. Lecturer gives apperception about the theory of learning media use.

c. Lecturers delivered the purpose of learning that was to gain experience related to learning media had been made by peers or classmates.

d. Lecturers directed students for presentation.

e. The results of the task of learning media were presented and then responded by partner (peers).

f. The other students except the both students responded to the learning media made by the presenter.

g. The lecturer responded or evaluated the learning media presented by the student

h. The students and the lecturer discussed to get the conclusion on the learning media had been presented

3. Observation

The teaching learning process in cycle 1 had been done well. In the first meeting of the first cycle, they way students presented was like teaching. Then the lecture suggested them only to deliver the media use. The students were still uncomfortable to comment about the learning media presented. The pair of the discussion could not give good suggestions to his friend. He did not give many opinions or comments to the pair. The other 
students even did not give any comments, it was only the pair who gave suggestions or commentary to the assignment had been presented. The other thing happened to the third presenter, he was like giving seminar rather than presenting the project of learning media. It took much time. The observation score of the students' communication in the first meeting of the first cycle was 1.875. This score shows that the ability of the students' communication was fair.

The teaching learning in the second meeting of the first cycle run well meaning that there was no meaningful obstacle. Students were still confused to deliver their opinions. There were not many comments. It was found that some of the students were talking during the lesson. The observation score of the students' communication ability in the second meeting was 2 . It shows that the ability of the students' communication was fair. 4.

Reflection

Based on the results of the observation, it shows that ability of the students' communication improved, however it was in fair category. Therefore, the second cycle was needed.

\section{CYCLE2}

1. Planning

In this phase, RPS was arranged for two meetings. The activities of lesson plan were designed for the empowerment of pair. Arranging observation sheet of the students communication and preparing documentation were done in this stage.

2. Action

The implementation of this stage was conducted for two meetings. The lecturer focused more on discussion activity. Students presented the results of the assignment that was mathematics learning media. Below are the activities done in this phase:

a. The lecturer checked for the students' readiness

b. Lecturer gives apperception about the theory of learning media use.

c. Lecturers delivered the purpose of learning that was to gain experience related to learning media had been made by peers or classmates.

d. Lecturers directed students for presentation.

e. The results of the task of learning media were presented and then responded by partner (peers).

f. The other students except the both students responded to the learning media made by the presenter.

g. The lecturer responded or evaluated the learning media presented by the student

h. The students and the lecturer discussed to get the conclusion on the learning media had been presented
3. Observation

The results of the observation in the first meeting of the second cycle show that the some students except the pair had already given their comments. They started to pay attention to the media being presented although they did comment much on it. It was found that some presenter did the presentation as they did microteaching. There was not enough time to discuss the media more. The observation score of the students' ability in communication was 3.125. This score was categorized as good.

The results of the observation in the second meeting in the second cycle show that there were more students commenting the presentation in longer time. The students became more fluent in commenting. The observation score of the students' ability in communication was 3.375. This score shows that the ability of the students; communication was categorized as good.

4. Reflection

Based on the results of observation on the students' communication, it can be seen that their ability in communication improved. The increase can be seen from the differences between the first cycle and the second cycle. It means that the students' ability in communication can be improved through assignments and peer empowerment in the subject of Mathematics learning media.

\section{Conclusions}

Based on the results of the research, it could be concluded that assignment and peer empowerment can improve the ability of the students' communication in the subject of Mathematics learning media. It is suggested that it needs some regulations in discussion process, then it eases the lecturer to direct students to convey their opinions. Duration also needs to be considered since the discussion process takes times.

\section{References}

Asikin, M. 2001. Komunikasi Matematika dalam RME. Makalah Seminar. Disajikan dalam Seminar Nasional RME di Universitas Sanata Darma. Yogyakarta., 14-15 Nopember 2001.

Arsyad, Azhar. 2002. Media Pembelajaran. Jakarta: PT Raja Grafindo Persada.

Kartadinata, Sunaryo. 1996. Buku Landasan Landasan Pendidikan. Dep DikBud.

Muzaqi. 2007. Peran Pendampingan dalam Pelaksanaan Pembelajaran di Pusat Kegiatan 
Belajar Masyarakat. Laporan. http:// www.damandiri.or.id/file/muzaqiunair.pdf

Sumantri, Mulyani, Permana, Johar. 2001. Buku Strategi Belajar Mengajar. Bandung : CV. Maulana.

Sumarmo, Utari. 2004. Pembelajaran Matematika untuk Mendukung PelaksanaanKurikulum Berbasis Kompetensi. The paper was presented in Mathematics Teacher Training Mathematics Major ITB. April 2004. 